\title{
Host preference of Tribolium castaneum (Herbst) on six kinds of flour
}

\section{Preferensi Tribolium castaneum (Herbst) pada enam jenis tepung}

\author{
Ludji Pantja Astuti*, Mutala'liah \\ Departemen Hama dan Penyakit Tumbuhan, Fakultas Pertanian, Universitas Brawijaya \\ Jalan Veteran, Malang 65145
}

(diterima April 2020, disetujui September 2020)

\begin{abstract}
The red flour beetle, Tribolium castaneum (Herbts) is a major pest of flour from various grains. The infested flour is discoloured and will emit a disagreeable odour due to the secretion of benzoquinone from the insect's abdominal glands. Considering the economic losses effected by $T$. castaneum, new alternative control measures are needed for this pest. This study sought to determine the host preferences of $T$. castaneum from amongst six kinds of flour to assess their vulnerability to infestation. The research was conducted in the Plant Pest Laboratory, Department of Plant Pests and Diseases, Faculty of Agriculture, University of Brawijaya. The host preferences of $T$. castaneum were examined using a six-arm olfactometer. Feeding preference tests were performed for a duration of 12 hours at $200 \mathrm{ml} /$ minute airflow in each chamber-arm, followed by oviposition preference observations one week later. Feeding preference was calculated for the total pool of adults observed, segregated by sex, whereas oviposition preference was calculated as the number of eggs laid. Flour nutrition (proximate composition, phenolic content, and riboflavin content) were analyzed. Our results showed a feeding preference by T. castaneum for bran, soy, and tapioca flour was greater over wheat, corn, and white gelatinous rice flour, while for oviposition, bran flour was the most preferred.
\end{abstract}

Key words: olfactometer, preferences, red flour beetle, storage pest

\begin{abstract}
ABSTRAK
Red flour beetle, Tribolium castaneum (Herbts) merupakan hama utama pada tepung yang berasal dari berbagai jenis biji. Tepung yang terinfestasi mengalami perubahan warna dan mengeluarkan bau yang tidak sedap akibat sekresi benzoquinone dari kelenjar perut $T$. castaneum. Mempertimbangkan kerugian ekonomi yang diakibatkan oleh T. castaneum, maka diperlukan tindakan pengendalian alternatif baru untuk hama ini. Penelitian ini bertujuan untuk mengetahui preferensi pakan $T$. castaneum dari enam jenis tepung untuk menilai kerentanannya terhadap infestasi hama tersebut. Penelitian dilakukan di Laboratorium Hama Tumbuhan, Jurusan Hama dan Penyakit Tumbuhan, Fakultas Pertanian, Universitas Brawijaya. Preferensi pakan T. castaneum diuji dengan menggunakan six-arm olfactometer. Uji preferensi makan dilakukan selama 12 jam pada aliran udara $200 \mathrm{ml} /$ menit di setiap chamber arm, dilanjutkan dengan pengamatan preferensi oviposisi pada satu minggu kemudian. Preferensi makan dihitung dari total serangga dewasa yang diamati, dan dipisahkan berdasarkan jenis kelamin, sedangkan preferensi oviposisi dihitung dari jumlah telur yang diletakkan. Nutrisi tepung (komposisi proksimat, kandungan fenol, dan riboflavin) dianalisis. Hasil penelitian menunjukkan bahwa preferensi makan $T$. castaneum lebih tinggi pada tepung dedak, tepung kedelai, dan tepung tapioka dibandingkan dengan tepung gandum, tepung jagung, dan tepung ketan putih, sedangkan untuk preferensi oviposisi, tepung dedak merupakan tepung yang paling disukai.
\end{abstract}

Kata kunci: hama penyimpanan, olfaktometer, preferensi, red flour beetle

\footnotetext{
*Penulis korespondensi: Ludji Pantja Astuti. Department of Plant Pests and Diseases, Faculty of Agriculture, University of Brawijaya
} Jalan Veteran, Malang 65145, Tel: +62-341-575843, Email: ludji_pa@ub.ac.id 


\section{INTRODUCTION}

Processed products, including flour, are particularly vulnerable to pest infestation during storage. Flour is a prominent food source and animal feedstock in Indonesia, deriving from plant ingredients. The primary flour pest in the worldwide is the red flour beetle (Tribolium castaneum (Herbts)) (Coleoptera: Tenebrionidae) (Emery \& Nayak 2007).

The red flour beetle or $T$. castaneum attacks various stored products, especially broken grain and processed products (Astuti et al. 2020). Red flour beetles prefer food sources high in B vitamin content. The infestation of stored products by $T$. castaneum during storage directly impacts product quantity and quality. Product losses caused by T. castaneum infestation may reach as high as approximately $34-40 \%$ (Ajayi \& Rahman 2006).

Direct effect of infestation by $T$. castaneum include decreased total flour mass, while indirect effects lead to flour discoloration and disagreeable odour due to benzoquinone by the pest (Appert 1987; Hodges et al. 1996). Product nutrient content may also be degraded. In addition, $T$. castaneum infestation may contaminate the product with exuviae and dead insect. Altering normal biochemical processes and preventing seed respiration. Moreover, biochemical activity in contaminated grain results in high heat and humidity, making further contamination by bacteria or fungi more likely (Lis et al. 2011).

Considering the damage caused by T. castaneum on various kinds of flour, this study aimed to determine the relative preference of $T$. castaneum for wheat flour, tapioca flour, corn flour, white gelatinous rice flour, soy flour, and bran flour. These flour types were selected flour based on their commercial availability. The vulnerability of flour products to infestation by $T$. castaneum can be discerned from the pest's behavioral preferences, as it chooses a suitable host as food and for oviposition. We expect results to inform methods for rearing $T$. castaneum and to inspire further research.

\section{MATERIALS AND METHOD}

\section{Study site and experimental design}

This research was conducted from April to August 2018 in the Plant Pest Laboratory, Department of Plant Pests and Diseases, Faculty of Agriculture, University of Brawijaya. Our study used completely randomized design (CRD), consisting of six treatments (testing types of flour, namely wheat flour, tapioca flour, corn flour, white gelatinous rice flour, soy flour, and bran flour) with four replications. A six-arm insect olfactometer (Figure 1) was used to observe the preference of T. castaneum for six kinds of flour. Each of the olfactometer arm is connected to an air flow meter and links to one flour type. Insects in the center of the instrument detect odours through their chemoreceptors and researchers can observe their attraction to each arm and flour sample (Brattoli et al. 2011)

\section{Preparation of test media and test insect}

Flour samples were sterilized according to Heinrichs et al. (1985), to eliminate contaminant organisms. Flour used in this study was kept in a freezer at $-15{ }^{\circ} \mathrm{C}$ for one week, then transferred into a refrigerator at $-5{ }^{\circ} \mathrm{C}$ for one week, and eventually transferred to containers at room temperature for at least two weeks. Proximate nutrition content of the flour was analyzed, including protein, fat, water, ash and carbohydrate; as well as phenolic content and vitamin analysis for riboflavin. T. castaneum insects came from the collections of the Plant Pest Laboratory, Department of Plant Pests and Diseases, Faculty of Agriculture, University of Brawijaya, where they had been reared on wheat flour and yeast (19:1) (Mostakim \& Khan 2014). Yeast had been added as a nutritional enrichment to the rearing media (Sacakli et al. 2013). F1 progeny were separated by sex during the pupal stage, using typical genitalia characteristics to differentiate the sexes (Figure 2) (Sreeramoju et al. 2016).

\section{Olfactory test to determine feeding preference}

Forty pairs of newly emerged T. castaneum adults were placed in the central chamber of the six-arm olfactometer for a total of 12 hours uninterrupted duration. Airflow in each of the olfactometer arms was set to $200 \mathrm{ml} /$ minutes. Study insects were allowed to freely move toward any arm according to their attraction to the odour emanating from the flour contained in the arm (Hao \& Zeng 2014). The mean number of males vs. females of T. castaneum attracted to each type of flour was calculated (Shafique et al. 2006; Din et al. 2018) with sex differentiated visually by noting patches on the ventral side of the anterior femur; males $T$. 


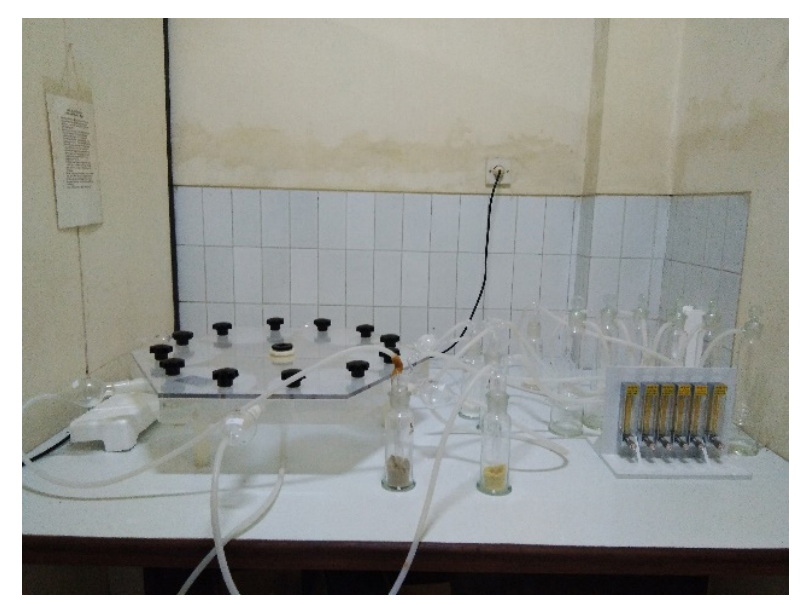

Figure 1. Six-arm insect olfactometer.

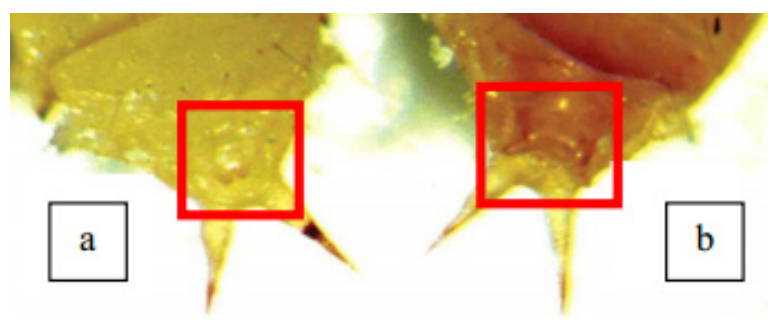

Figure 2. Genitalia of T. castaneum pupae. a: male, b: female (Sreeramoju et al. 2016).

castaneum exhibit the patches but females do not (Wahedi et al. 2015). This test was repeated four times.

\section{Oviposition preference}

A no choice method was performed to study oviposition preference. A set number of test insects taken directly from the feeding test, placed in glass tubes containing $30 \mathrm{~g}$ of same kinds of flour. The test insects were allowed to feed and lay their eggs for seven days, then the number of eggs observed on particles of each type of flour, as seen under a stereo microscope was recorded (Heinrichs et al. 1985). This test was repeated four times.

\section{Nutritional content analysis}

Samples of the six kinds of flour were sent to Faculty of Agricultural Technology, University of Brawijaya for proximate and phenolic content analysis, while riboflavin analysis was conducted at the Integrated Research and Testing Laboratory, Universitas Gadjah Mada. Proximate content was analyzed as follows: Protein was determined by the Kjeldahl method (Maehre et al. 2018); fat was measured via the Caviezel method using gas chromatography (Pendl et al. 1998); water and ash content was measured according to methods published in document SNI 01-2891-1992 section 5.1 for water content and section 6.1 for ash content; and carbohydrate was calculated according to the formula: $(100 \%$ - protein $(\%)$ - fat $(\%)$ - ash $(\%)$ - water content (\%)). Phenolic content measured using spectrophotometric apparatus (Astuti et al. 2013), while riboflavin was tested using high performance liquid chromatography (HPLC). These analysis were used to identify any correlation between different nutrient content characteristics, and feeding and oviposition preferences of $T$. castaneum.

\section{Observed variables}

The observed variables were the total number of insects, as well as their proportion of males and females, found on each kind of flour (during the feeding test), and the number of eggs laid on each kind of flour (during the oviposition test). In addition, nutrition content variables were analyzed: proximate and phenolic content, and riboflavin levels.

\section{Data analysis}

$R$ 3.5.1. Software was used for analysis of variance (ANOVA) and Duncan's multiple range test (DMRT) at $\alpha 5 \%$ was performed to determine significant differences in feeding and oviposition preferences of $T$. castaneum for six types of flour tested. Correlation analysis was performed to ascertain any relationship between nutrient content variables and the number of attracted test insects, or eggs laid.

\section{RESULTS}

\section{Feeding preference}

Feeding preference is reflected by the mean number of $T$. castaneum individuals attracted to each type of test flour during the feeding test. Results showed that the $T$. castaneum regardless of sex, exhibited significantly greater preference $(\mathrm{P}<0.05)$ for bran, soy, and tapioca flour than for wheat, corn, and white gelatinous rice flour $\left(\mathrm{F}_{6,21}=\right.$ 6,$35 ; \mathrm{P}=0,0006$ ) (Table 1). There was no statistical difference between the number of $T$. castaneum individuals observed to be attracted to bran, soy, or tapioca flour. Similarly, there was no statistical different between the number of $T$. castaneum 
Table 1. Feeding preference of Tribolium castaneum on various kinds of flour

\begin{tabular}{lccc}
\hline \multirow{2}{*}{ Flour Type } & \multicolumn{3}{c}{ Mean number of T. castaneum } \\
\cline { 2 - 4 } & Male* & Female* & Total* \\
\hline Bran & $7.75 \pm 0.49 \mathrm{ab}$ & $11.00 \pm 0.89 \mathrm{a}$ & $18.75 \pm 1.29 \mathrm{a}$ \\
Soy & $6.50 \pm 0.31 \mathrm{abc}$ & $7.50 \pm 0.33 \mathrm{ab}$ & $14.00 \pm 0.39 \mathrm{ab}$ \\
Wheat & $3.00 \pm 0.95 \mathrm{c}$ & $3.50 \pm 0.33 \mathrm{~cd}$ & $6.25 \pm 1.28 \mathrm{c}$ \\
Corn & $4.50 \pm 0.11 \mathrm{bc}$ & $6.00 \pm 0.41 \mathrm{bc}$ & $10.50 \pm 0.45 \mathrm{bc}$ \\
White glutinous rice & $5.50 \pm 0.44 \mathrm{bc}$ & $3.00 \pm 0.26 \mathrm{~cd}$ & $8.50 \pm 0.57 \mathrm{c}$ \\
Tapioca & $10.50 \pm 0.76 \mathrm{a}$ & $7.75 \pm 0.42 \mathrm{ab}$ & $18.50 \pm 1.17 \mathrm{a}$ \\
No insects chosed & $2.00 \pm 0.34 \mathrm{c}$ & $1.50 \pm 0.11 \mathrm{~d}$ & $3.50 \pm 0.39 \mathrm{c}$ \\
\hline
\end{tabular}

*: Mean \pm SE followed by different letters in the same column are significantly different $(\alpha<0.05)$.

individuals observed to be attracted to wheat, corn, and white gelatinous rice flour. A total of 3.5 out of 80 test insects did not exhibit attraction to any type of flour. Such a small proportion $(4.37 \%)$ of non-attracted test insects demonstrates that the six-arm olfactometer test method was adequate to determine the feeding preference of $T$. castaneum for various kinds of flour.

\section{Oviposition preference}

Oviposition preference was reflected in the number of eggs laid on each treatment flour by T. castaneum females. The mean number of eggs oviposited on bran flour was significantly higher (658 eggs) than all other flour types $\left(\mathrm{F}_{5,18}=\right.$ $8,645 ; \mathrm{P}=0,0002)$ (Table 2). Correlation analyses indicate, a positive correlation between number of eggs laid $(r=0.66)$ and the number of female insects attracted to all types of flour treatment in the olfactory test. A higher the number of $T$. castaneum female insects attracted to all types of flour correlated with a higher number of eggs laid. The number of eggs oviposited on soy, wheat, corn, white gelatinous rice, and tapioca flour was not significantly different. Thus, bran flour was demonstrated to be a suitable food source allowing for $T$. castaneum oviposition.

This study also sought to identify any relationship between flour nutritional content and the $T$. castaneum host preferences, and to determine which if any factor was most influential. Results showed a positive correlation between ash content $(r=0.4)$ and total adult feeding preference, but no such correlation to other factors. There was no correlation between any of the nutritional variables and number of males attracted to a flour; however, the mean number of females
Table 2. Mean number of Tribolium castaneum eggs laid on various kinds of flour

\begin{tabular}{lc}
\hline Flour types & Number of eggs* \\
\hline Bran & $658.00 \pm 69.17 \mathrm{a}$ \\
Soy & $151.50 \pm 20.35 \mathrm{~b}$ \\
Wheat & $230.50 \pm 13.38 \mathrm{~b}$ \\
Corn & $107.00 \pm 9.75 \mathrm{~b}$ \\
White glutinous rice & $68.50 \pm 12.59 \mathrm{~b}$ \\
Tapioca & $96.25 \pm 9.84 \mathrm{~b}$ \\
\hline
\end{tabular}

*: Mean \pm SE followed by different letters in the same column are significantly different $(\alpha<0.05)$.

attracted positively correlated with ash $(\mathrm{r}=0.59)$ and phenolic content $(r=0.45)$. This result was repeated with regard to the number of eggs laid. Number of eggs laid correlated positively to ash and phenolic content, i.e., $r=0.77$ and $r=0.51$, respectively. Moreover, riboflavin levels $(r=0.46)$ also positively correlated to the number of eggs laid (Table 4). Ash content and riboflavin levels in bran flour was highest $(9.43 \%)$ and $(0.94 \mathrm{mg} /$ $\mathrm{kg}$ ) as compared to all flour types (Table 3), while phenolic content was greater in soy $(0.14 \%)$ and bran flour $(0.12 \%)$ than four other flour types.

\section{DISCUSSIONS}

Host preference of $T$. castaneum on various kinds of flour regarding the feeding and oviposition preference was influenced by ash content, phenolic content, and riboflavin levels of flour. The greater the ash content in a flour, the higher the number of $T$. castaneum present in the "bran arm" of the olfactometer (Khaliq et al. 2014). Similarly, and as expected, female numbers in the olfactometer test, also positively correlated with ash and phenolic 
Table 3. Nutrient content of six flour types

\begin{tabular}{lrrrrrr}
\hline \multirow{2}{*}{ Nutrient content } & \multicolumn{7}{c}{ Flour type } \\
\cline { 2 - 7 } & Bran & \multicolumn{1}{c}{ Soy } & Wheat & Corn & White sticky rice & Tapioca \\
\hline Phenolic (\%) & 0.12 & 0.14 & 0.05 & 0.02 & - & - \\
Protein (\%) & 8.27 & 28.30 & 9.06 & 0.91 & 4.81 & 1.46 \\
Fat (\%) & 5.21 & 17.71 & 1.68 & 0.08 & 0.29 & 0.09 \\
Water (\%) & 11.39 & 5.21 & 9.89 & 10.47 & 10.54 & 11.44 \\
Ash (\%) & 9.43 & 4.45 & 1.26 & 0.02 & 0.20 & 0.08 \\
Carbohydrate (\%) & 65.70 & 44.33 & 78.11 & 88.52 & 84.16 & 86.93 \\
Riboflavin (mg/kg) & 0.94 & 0.14 & 0.38 & 0.19 & 0.92 & 0.19 \\
\hline
\end{tabular}

Table 4. The correlation coefficient of flour nutrition content to feeding and oviposition preference of Tribolium castaneum on various kinds of flour

\begin{tabular}{lcccc}
\hline Nutrition content & Total & Male & Female & Egg \\
\hline Phenol & 0.24 & -0.01 & $0.45^{*}$ & $0.51^{*}$ \\
Protein & 0.03 & -0.06 & 0.13 & 0.06 \\
Fat & 0.17 & 0.03 & 0.27 & 0.12 \\
Water & 0.10 & 0.14 & 0.03 & 0.20 \\
Ash & $0.40^{*}$ & 0.13 & $0.59^{*}$ & $0.77^{*}$ \\
Carbohydrate & -0.19 & -0.02 & -0.32 & -0.28 \\
Riboflavin & 0.01 & -0.03 & 0.04 & $0.46^{*}$ \\
\hline
\end{tabular}

content. Phenolic content in soy flour and bran flour was higher than in other kinds of flour, i.e., 0.14 and 0.12 (Table 3). A higher content of ash and phenolic content will increase the number of females attracted to flour to feed. This aligns with Kayode et al. (2014), who stated that because ash content in millet flour is higher than in corn, wheat, and sorghum flour, millet flour is more susceptible to infestation by T. castaneum. Mehmood et al. (2018) noted that they found higher ash content products that experience many pest infestation in storage. Bran flour, which contained the highest ash levels, experienced the worst pest infestation, whereas ash content is lowest in corn flour, which has little to no infestation. The researchers postulate that high ash content might capture odours that attract stored product pests, resulting in high infestation in high-ash product. In addition to pest infestation, length of time in storage is another factor that may cause an increase in ash content for grain products (Samuels \& Modgil 2003).

Results of our oviposition preference test showed a positive correlation between the number of eggs laid and the ash, phenolic, and riboflavin content of flour. Ash content demonstrated a stronger effect on number of eggs laid than did phenolic and riboflavin content. The number of eggs laid on products with higher ash content will be greater than the number of eggs laid on products with low ash content (Mahmoud 2011). Astuti et al. (2013) also found that grain product ash content positively correlated with the number of eggs laid by a female insect. Phenolic content of feed was expected to act as an oviposition stimulant. Sambaraju \& Philips (2008) revealed that the addition of hexane extract to grain-based feed could significantly increase the oviposition numbers of Plodia interpunctella (Hübner). Similarly, for Lobesia botrana (Denis \& Schiffermüller), oviposition increased when methanol was added to the feed. Polar compounds, both volatile and non-volatile, can be useful as oviposition stimulants when added to food sources (Maher \& Thiery 2004).

In this study we found that riboflavin content was highest in bran flour $(0.94 \mathrm{mg} / \mathrm{kg}$ ) (Table 3) and that $T$. castaneum deposited more eggs in bran flour. Riboflavin is a B vitamin (B2), an organic compound that is needed by insects in small amounts. Other kinds of $\mathrm{B}$ vitamin required by insects include thiamine (B1), nicotinic acid (B3), 
pyridoxine (B4), pantothenic acid (B5), folic acid (B6), and biotin (B7) (Chapman 1998). Riboflavin plays a vital role in the growth and development of insects, which has been shown to be especially true for Tribolium spp. This aligns with Fraenkel \& Blewett (1943), demonstrates that Tribolium more require riboflavin than Silvanus, Lasioderma, and Sitodrepa. In addition, Hamalainen \& Loschiavo (1977), reported that the addition of riboflavin to feed could increase the fecundity of $T$. confusum and $T$. castaneum females, although the addition of thiamine and niacin did not have this effect.

\section{CONCLUSIONS}

Flour made from bran, soy, and tapioca were preferred at significantly greater rates by T. castaneum for feeding, than wheat, corn, and white gelatinous rice flour, and bran flour was the most suitable for egg production.

\section{ACKNOWLEDGEMENT}

The authors would like to thank Radi Firnanda for helping with research observation.

\section{REFERENCES}

Ajayi FA, Rahman SA. 2006 Susceptibility of some staple processed meals to red flour beetle, Tribolium castaneum (Herbst) (Coleoptera: Tenebrionidae). Pakistan Journal of Biological Sciences 9:1744-1748. doi: https://doi. org/10.3923/pjbs.2006.1744.1748.

Appert J. 1987. The Storage of Food Grains and Seeds, The Tropical Agriculturalist CTA. London: Macmillan Publishers Ltd.

Astuti LP, Mudjiono G, Rasminah ChS, Rahardjo BT. 2013. Susceptibility of milled rice varieties to the lesser grain borer (Rhyzopertha dominica F.). Journal of Agricultural Science 5:145-149. doi: https://doi.org/10.5539/jas.v5n2p145.

Astuti LP, Lestari YE, Rachmawati R, Mutala'liah. 2020. Preference and development of Tribolium castaneum (Herbst 1797) (Coleoptera: Tenebrionidae) in whole grain and flour form of five corn varieties. Biodiversitas 21:564-569. doi: https://doi.org/10.13057/biodiv/d210218.
Brattoli M, de Gennaro, de Pinto V, Loiotile AD, Lovascio S, Penza M. 2011. Odour detection methods: olfactory and chemical sensors. Sensors 11:5290-5322. doi: https://doi.org/10.3390/ s110505290.

Chapman RF. 1998. The Insects: Structure and Function, $4^{\text {th }}$ ed. Cambridge University Press. doi: https://doi.org/10.1017/CBO9780511818202.

Din N, Ashraf M, Hussain S, Iqbal Z, Hussain D. 2018. Feeding preference and biology of Tribolium castaneum Herbst (Coleoptera: Tenebrionidae) in different wheat varieties. Journal of Entomology and Zoology Studies 6:147-150.

Emery RN, Nayak MK. 2007. Cereals: Pest of stored grains. In: Bailey PT (Ed.), Pests of Fields Crops and Pastures: Identification and Control. pp. 40-62. Collingwood: CSIRO Publishing.

Fraenkel G, Blewett M. 1943. Vitamins of the B-group required by insects. Nature 151:703704. doi: https://doi.org/10.1038/151703a0.

Hamalainen MK, Loschiavo SR. 1977. Effect of synthetic B-Vitamin and natural enrichment of flour on larval development and fecundity of Tribolium confusum and T. castaneum. Entomologia Experimentalis et Applicata 21:2937.doi:https://doi.org/10.1111/j.1570-7458.1977. tb02653.x.

Hao GH, Zeng L. 2014. Olfactory response of Cryptolestes turcius (Grouvelle) to six varieties of grain. In: Arthur FH, Kengkanpanich R, Chayaprasert W, Suthisut D (Eds.), Proceedings of the 11th International Working Conference on Stored Product Protection (Chiang Mai, 24-28 November 2014). pp. 152-157. Chiang Mai: IWCSPP.

Heinrichs EA, Medrano EG, Rapusas HR. 1985. Genetic Evaluation for Insect Resistance in Rice. Los Banos: International Rice Research Institute.

Hodges RJ, Robinson R, Hall DR. 1996. Quinone contamination of dehusked rice by Tribolium castaneum (Herbst) (Coleoptera: Tenebrionidae). Joural of Stored Product Research 32:31-37. doi: https://doi.org/10.1016/0022-474X(95)00036-7.

Kayode OY, Adedire CO, Akinkurolere RO. 2014. Influence of for cereal flours on the growth of Tribolium castaneum Herbst (Coleoptera: Tenebrionidae). Life Journal of Science 6:505516.

Khaliq A, Sagheer M, Javed M. 2014. Estimation of quality deterioration in different rice genotypes infested by Tribolium castaneum (Herbst) under a biotic stress. Cercetari Agronomice in Moldova 
XLVII:47-56. doi: https://doi.org/10.2478/ cerce-2014-0026.

Lis LB, Bakula T, Baranowski M, Czarnewicz A. 2011. The carcinogenic effects of benzoquinones produced by the flour beetle. Polish Journal of Veterinary Sciences 14:159-164. doi: https://doi. org/10.2478/v10181-011-0025-8.

Maehre HK, Dalheim L, Edvinsen GK, Elvevoll EO, Jensen IJ. 2018. Protein determination method matters. Foods 7:1-11. doi: https://doi. org/10.2478/v10181-011-0025-8.

Maher N, Thiery D. 2004. A bioassay to evaluate the activity of chemical stimuli from grape berries on the oviposition of Lobesia botrana (Lepidoptera: Totricidae). Bulletin Entomological Research 94:27-33. doi: https://doi.org/10.1079/ BER2003276.

Mahmoud HAFH. 2011. Response of Sitotroga cerealella to Semiochemicals and Physical Characteristic of Corn Kernels. PhD Thesis. Universidade Federal de Vicosa.

Mehmood K, Husain M, Aslam M, Ahmedani MS, Aulakh AM, Shaheen FA. 2018. Change in the nutritional composition of maize flour due to Tribolium castaneum infestation and application of carbon dioxide to manage this pest. Environmental Science and Pollution Research 25:18540-18547. doi: https://doi.org/10.1007/ s11356-018-2063-6.

Mostakim Md, Khan AR. 2014. Effect of coffee on the growth and development of the red flour beetle, Tribolium castaneum (Herbst) (Coleoptera: Tenebrionidae). Bangladesh Journal of Zoology 42:211-216. doi: https://doi.org/10.3329/bjz. v42i2.23363.

Pendl R, Bauer M, Caviezel R, Schulthess P. 1998. Determination of total fat in foods and feeds by the caviezel method, based on a gas chromatographic technique. Journal of $A O A C$ International 81:907-917. doi: https://doi. org/10.1093/jaoac/81.4.907.
Sacakli P, Koksal BH, Ergun A, Ozsoy B. 2013. Usage of Brewer"s yeast (Saccharomyces cerevisiae) as a replacement of vitamin and trace mineral premix in broiler diets. Revue de Medecine Veterinaire 164:39-44.

Sambaraju KR, Phillips TW. 2008. Effect of physical and chemical factors on oviposition by Plodia interpunctella (Lepidoptera: Pyralidae). Entomological Society of America 101:955-963. doi: https://doi.org/10.1603/00138746(2008)101[955:EOPACF]2.0.CO;2.

Samuels R, Modgil R. 2003. Physico-chemical changes in insect infested wheat stored indifferent storage structures. Indian Journal of Agricultural Science 73:562-563.

Shafique MM, Ahmad MA, Chaudry. 2006. Feeding preference and development of Tribolium castaneum (Herbst.) in wheat products. Pakistan Journal of Zoology 3:27-31.

Sreeramoju PM, Prasad SK, Lakshmipathi V. 2016. Complete study of life cycle of Tribolium castaneum and its weight variations in the developing stages. International Journal of Plant, Animal, and Environmental Sciences 6: 95-100.

Wahedi JA, David DL, Zakariya R, Mshelmbula BP, Danba EP, Buba U, Barau BW, Usman DD, Tarfa F. 2015. Effect of Sex differentiation on Tribolium castaneum development reared on four selected grain flours. Annals of Biological Research 6:7-10. 